[17] Chazaud, B. (2015). Inflammation during skeletal muscle regeneration and tissue remodeling: application to exercise-induced muscle damage management. Immunology and Cell Biology, 94 (2), 140-145. doi: http://doi.org/10.1038/icb.2015.97

[18] Duchesne, E., Dufresne, S. S., Dumont, N. A. (2017). Impact of Inflammation and Anti-inflammatory Modalities on Skeletal Muscle Healing: From Fundamental Research to the Clinic. Physical Therapy, 97 (8), 807-817. doi: http://doi.org/10.1093/ptj/pzx056

[19] Iizuka, M., Konno, S. (2011). Wound healing of intestinal epithelial cells. World Journal of Gastroenterology, 17 (17), $2161-$ 2171. doi: http://doi.org/10.3748/wjg.v17.i17.2161

[20] Nakanishi, M., Rosenberg, D. W. (2012). Multifaceted roles of PGE2 in inflammation and cancer. Seminars in Immunopathology, 35 (2), 123-137. doi: http://doi.org/10.1007/s00281-012-0342-8

\title{
THE METHOD OF FORECASTING OF THE INDICATORS FOR DRUG REIMBURSEMENT TO PATIENTS WITH CARDIOVASCULAR DISEASES IN UKRAINE
}

\author{
Alla Nemchenko \\ Department of Organization and Economy of Pharmacy \\ National University of Pharmacy \\ 53 Pushkinska str., Kharkiv, Ukraine, 61002 \\ Viktoriya Nazarkina \\ Department of Organization and Economy of Pharmacy \\ National University of Pharmacy \\ 53 Pushkinska str., Kharkiv, Ukraine, 61002 \\ Yuliia Kurylenko \\ Department of Organization and Economy of Pharmacy \\ National University of Pharmacy \\ 53 Pushkinska str., Kharkiv, Ukraine, 61002
}

\begin{abstract}
The aim of the study is to develop a method for forecasting the indicators for drug reimbursement to patients with cardiovascular diseases (CVD) in Ukraine within the framework of the government program "Available medicines".

Materials and methods: materials of the State Statistics Service of Ukraine and medical records of patients with CVD, who were prescribed with medicines according to the government program, were used in the study.

Results: according to the method proposed for forecasting the volume of drug reimbursement to patients with CVD under the government program it has been found that Enalapril has the highest indicator - 10916.4 USD thousand in 2019 and 10736.8 USD thousand in 2020. Clopidogrel takes the second position - 12108.13 USD thousand and 11908.24 USD thousand, while Amlodipine occupies the third position - 9105.60 USD thousand and 8955.28 USD thousand.

Among the medicines not included in the government program, but prescribed rather frequently the largest forecasting amount required for reimbursement (in case of inclusion in the program) is 18910.55 USD thousand in 2019 and 18598.36 USD thousand in 2020 for Magnicor, and the least amount is 444.55 USD thousand and 437.22 USD thousand for Acetylsalicylic acid, respectively.

Conclusions. The government program to provide patients with effective and affordable medicines has a significant impact on reforming the healthcare system of Ukraine. The study conducted can be used to expand the government program in the process of formation and distribution of budget funds.
\end{abstract}

Keywords: cardiovascular diseases, forecasting, reimbursement, medicines, healthcare. 


\section{Introduction}

Cardiovascular diseases (CVD) hold a leading place in the world among other nosology's by the number of deaths of the working-age population. In the field of healthcare of the leading countries of the world, the government programs for drug reimbursement are increasingly introduced to improve the availability and quality of medical and pharmaceutical care to all segments of the population [1-3]. Since 2012, government projects and programs to increase the availability of pharmaceutical care to all segments of the population have been implemented in the healthcare of Ukraine. In 2017, the government program "Available medicines" was introduced with the aim of providing patients with life-saving necessary medicines for the treatment of nosologies, such as CVD, asthma and type II diabetes [3]. In the same year, thanks to the support of Management Sciences for Health (MSH), the project "Safe, available and effective medicines for Ukrainians" (SAFEMed) began its work in Ukraine. Its main goal is to improve the financing mechanisms of the national healthcare system [4].

As practice has shown, the pharmacotherapy of CVD is quite expensive and long due to the peculiarity of the disease course and the presence of concomitant nosologies in a patient. Therefore, the rational use of budgetary funds is one of the main components for further development of the healthcare system.

\section{Aim of the research}

The aim of our study was to develop a method for predicting the indicators for drug reimbursement to patients with CVD in Ukraine within the framework of the government program "Available medicines".

\section{Materials and methods}

Materials from the official Express issues formed by the State Statistics Service of Ukraine (within 2013-2018); medical records of patients with CVD, who were prescribed medicines according to the government program for reimbursement; the data of our preliminary pharmacoeconomical analysis of treatment regimens of patients with CVD were used in the study [5-7]. Statistical, analytical, mathematical methods and the method of generalization of scientific information were applied in the work. The method of the study is presented in Fig. 1.

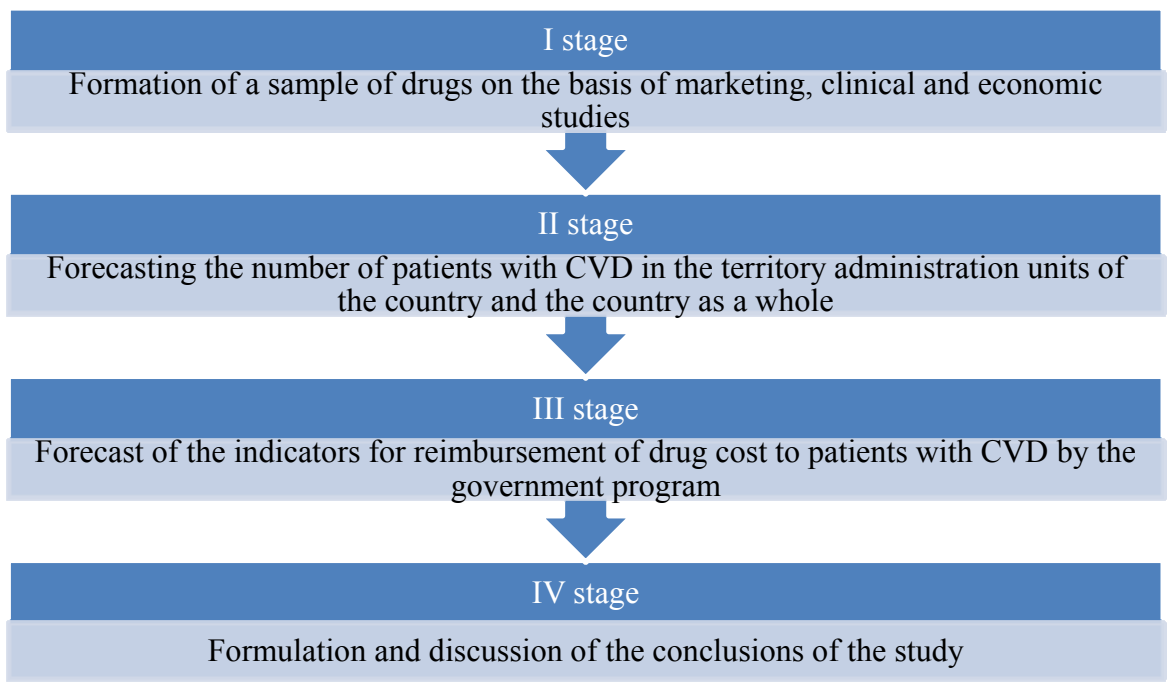

Fig. 1. The research method for predicting the indicators for drug reimbursement to patients with cardiovascular diseases

Despite the fact that CVD have a significant variation in morbidity indicators their ranking by regions of Ukraine was conducted according to three groups (Table 1). 
Table 1

The results of ranking the Ukrainian regions by the level of CVD morbidity in 2018

\begin{tabular}{|c|c|c|}
\hline Group & Morbidity per 100 thousand people & Regions \\
\hline I & $1965-3622$ & Khersonska, Cherkaska, Zaporizka, Volynska regions \\
\hline II & $3623-5280$ & $\begin{array}{l}\text { City of Kyiv; Chernihivska, Chernivetska, Khmelnytska, Kharkivska, Ternopil- } \\
\text { ska, Sumska, Rivnenska, Poltavska, Odeska, Lvivska, Kirovohradska, Kyivska, } \\
\text { Zakarpatska, Zhytomyrska, Vinnytska regions }\end{array}$ \\
\hline III & $5281-6938$ & Mykolaivska, Ivano-Frankivska, Dnipropetrovska regions \\
\hline
\end{tabular}

The first group contained regions with low morbidity, for which fluctuations in the incidence were within 1965-3622 cases; in the second group there were regions with an average incidence of 3623-5280 cases, and the third group comprised regions of Ukraine with a high incidence of CVD, which incidence rate ranged from 5281 to 6938 cases per 100 thousand population. In total, the first and second group included 20 regions, which was $86.95 \%$ of the total number of territory administration units. In the third group there were three regions with the share of $13.05 \%$. It should be noted that they are industrial-agricultural and port regions of Ukraine, their highest incidence rate is characterized by inadequate indicators of quality of life.

For calculations, the program STATISTICA was used for each region of the country, and the regression loglinear model and the determination coefficient were calculated. Prognosis of indicators of prevalence of patients with CVD in territory administration units of the country was done for 2019-2020 (per 100 thousand of the population).

\section{Result}

The low level of state funding, inefficient allocation of budget funds between regions of the country and their spending are the main problems of development of the healthcare system of Ukraine [8]. As a result, patients have to pay most of the money for the treatment from their family budget. In this regard, the solution of these problems is a priority in further development and reforming of the national healthcare in Ukraine. [9]. Thus, the proper access of all segments of the population to timely, high-quality and affordable medical and pharmaceutical care is possible only with reasonable calculations of indicators of drug reimbursement, in particular under the government programs [10].

According to the method proposed for forecasting the volume of drug reimbursement to patients with CVD under the government program it has been found that Clopidogrel has the highest indicator - 12108.13 USD thousand in 2019 and 11908.24 USD thousand in 2020 (Table 2).

Enalapril takes the second position - 10916.39 USD thousand and 10736.18 USD thousand, while Amlodipine occupies the third position - 9105.60 USD thousand and 8955281.42 USD thousand. Among the medicines not included in the government program, but prescribed rather frequently the largest forecasting amount required for reimbursement (in case of inclusion in the program) is 18910.55 USD thousand in 2019 and 18598.36 USD thousand in 2020 for Magnicor, and the least amount is 444.55 USD thousand and 437.22 USD thousand for Acetylsalicylic acid, respectively. At the next stage, drug reimbursement for patients with CVD in the regions of the country for 2019 and 2020 was calculated (Table 3). The regions of the country were located according to the ranking, which is shown in Table 1.

Thus, for 2019 and 2020, the highest indicators among medicines recommended for inclusion in the program under condition of its expansion are observed in the Mykolaivska region for Magnicor, $75 \mathrm{mg}$, No. 100, - 1338.71 USD thousand and 1348.71 USD thousand, respectively, while the lowest indicators are in the Khersonska region for Acetylsalicylic acid, $500 \mathrm{mg}$, No.10, - 6.70 USD thousand and 4.20 USD thousand, respectively. Among medicines included in the program "Available medicines" the highest indicator for reimbursement in 2019 is for Clopidogrel, $75 \mathrm{mg}$, No. $90-857.15$ USD thousand in the Mykolaivska region, and the lowest indicator is for Hydrochlorothiazide, $25 \mathrm{mg}$, No. 20 39.71 USD thousand in the Khersonska region. In 2020 the highest indicator is in the Mykolaivska region for Clopidogrel, $75 \mathrm{mg}$, No.90 - 863.56 USD thousand, while the lowest indicator is for Hydrochlorothiazide, $25 \mathrm{mg}$, No.20 - 25.29 USD thousand in the Khersonska region, respectively. It 
should be noted that there is a relationship between the results of ranking the regions of Ukraine by the incidence of CVD and the volume of the forecasting amount of compensation.

Table 2

The forecasting indicators of reimbursement recommended for patients with CVD

\begin{tabular}{|c|c|c|c|c|c|c|}
\hline $\begin{array}{c}\text { Drug name / } \\
\text { Dosage }\end{array}$ & $\begin{array}{l}\text { Intensity of } \\
\text { drug prescrip- } \\
\text { tion (absolute } \\
\text { indicator) }\end{array}$ & $\begin{array}{l}\text { Intensity of } \\
\text { drug prescrip- } \\
\text { tion, } \%\end{array}$ & $\begin{array}{c}K_{i} \text { of intensity of } \\
\text { drug prescrip- } \\
\text { tion }\end{array}$ & $\begin{array}{l}\text { The average } \\
\text { cost of treat- } \\
\text { ment, USD }\end{array}$ & $\begin{array}{l}\text { Theforecasting } \\
\text { amount of drug } \\
\text { reimbursement } \\
\text { for } 2019 \text {, } \\
\text { USD thousand }\end{array}$ & $\begin{array}{l}\text { Theforecasting } \\
\text { amount of drug } \\
\text { reimbursement } \\
\text { for } 2020 \text {, } \\
\text { USD thousand }\end{array}$ \\
\hline $\begin{array}{l}\text { Clopidogrel, } 75 \\
\text { mg, No. } 90\end{array}$ & 413 & 5.26 & 0.347 & 353.45 & 12108.13 & 11908.24 \\
\hline $\begin{array}{l}\text { Magnicor, } 75 \\
\text { mg, No. } 100\end{array}$ & 870 & 11.08 & 0.731 & 262.04 & 18910.55 & 18598.36 \\
\hline $\begin{array}{l}\text { Simvastatin, } 40 \\
\text { mg, No. } 28\end{array}$ & 191 & 2.43 & 0.161 & 226.62 & 3601.97 & 3542.50 \\
\hline $\begin{array}{l}\text { Enalapril, } 20 \\
\text { mg, No.20 }\end{array}$ & 526 & 6.7 & 0.442 & 250.17 & 10916.39 & 10736.18 \\
\hline $\begin{array}{l}\text { Amlodipine, } 5 \\
\text { mg, No. } 30\end{array}$ & 484 & 6.16 & 0.407 & 226.62 & 9105.60 & 8955.28 \\
\hline $\begin{array}{l}\text { Bisoprolol, } 5 \mathrm{mg} \text {, } \\
\text { No. } 50\end{array}$ & 184 & 2.34 & 0.155 & 226.54 & 3466.62 & 3409.39 \\
\hline $\begin{array}{l}\text { Verapamil, } 40 \\
\text { mg, No. } 20\end{array}$ & 160 & 2.04 & 0.134 & 228.50 & 3022.77 & 2972.87 \\
\hline $\begin{array}{l}\text { Acetylsalicylic } \\
\text { acid, } 500 \mathrm{mg}, \\
\text { No. } 10\end{array}$ & 21 & 0.27 & 0.018 & 250.17 & 444.55 & 437.22 \\
\hline $\begin{array}{l}\text { Atenolol, } 100 \\
\text { mg, No. } 20\end{array}$ & 181 & 2.29 & 0.151 & 226.96 & 3383.42 & 3327.57 \\
\hline $\begin{array}{l}\text { Hydrochloro- } \\
\text { thiazide, } 25 \mathrm{mg} \text {, } \\
\text { No. } 20\end{array}$ & 143 & 1.82 & 0.12 & 223.33 & 2645.79 & 2602.11 \\
\hline
\end{tabular}

Note: the USD exchange rate as of 28.11.2018 - $1 U S D=28,11 \mathrm{UAH}$

Thus, the highest forecasting amount of compensation was determined in the Mykolaivska region, which was referred in the process of ranking to the third group of regions with a high incidence of the population, and the smallest figures of the estimated amounts of compensation were observed in the Khersonska region referred to the first group - regions with low morbidity of the population. The overall average indicators of drug reimbursement in Ukraine are 67605.8 USD thousand for 2019, and 65604.2 USD thousand for 2020. The overall average indicator of forecasting drug reimbursement in the regions of the country per one patient was also calculated and ranked in three groups (Tables 4, 5).

In particular, for 2019 the first group contained such medicines as Acetylsalicylic acid, Hydrochlorothiazide, Verapamil, Atenolol, Enalapril, Simvastatin in all regions, Amlodipine was only by the indicator in the Khersonska, Kharkivska and Vinnytska regions, Enalapril and Clopidogrel were only by the indicator in the Khersonska region. In the second group there were Amlodipine, Clopidogrel, Enalapril in all regions except those referred to the first group and Magnicor was only by the indicators in the Khersonska and Vinnytska regions. Magnicor was in the third group in all regions except the Khersonska and Vinnytskaregions. For 2020 the first group contained such medicines as Acetylsalicylic acid, Hydrochlorothiazide. Verapamil, Atenolol, Enalapril, Simvastatin, while Amlodipine was included in this group in the Khersonska, Vinnytska, Cherkaska regions by the indicators. Enalapril, Clopidogrel, Magnicor were also included in the first group by the indicator of drug consumption per one patient in the Khersonska region. 
Table 3

The forecasting amount of drug reimbursement recommended for the treatment of CVD in the regions of the country for 2019 and 2020

\begin{tabular}{|c|c|c|c|c|c|c|c|c|c|c|}
\hline 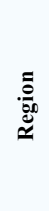 & 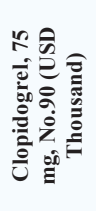 & 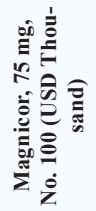 & 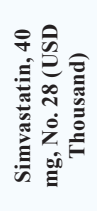 & 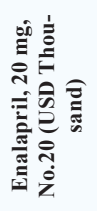 & 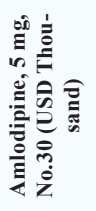 & 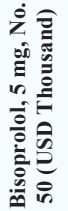 & 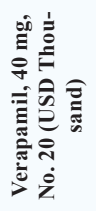 & 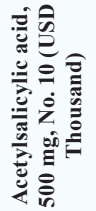 & 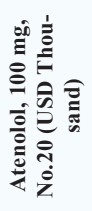 & 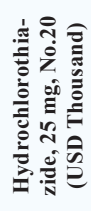 \\
\hline
\end{tabular}

\begin{tabular}{|c|c|c|c|c|c|c|c|c|c|c|c|c|c|c|c|c|c|c|c|c|}
\hline ્ٍટ & సे & స్ & & జิ & $\stackrel{\overline{\tilde{N}}}{ }$ & స్ & डิ & స్ & $\stackrel{\bar{\Xi}}{\mathrm{N}}$ & క్ & 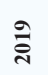 & స్ & సे & జิ & 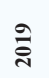 & స్ & 亏े & స్ & 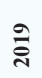 & สิ \\
\hline 1 & 2 & 3 & 4 & 5 & 6 & 7 & 8 & 9 & 10 & 11 & 12 & 13 & 14 & 15 & 16 & 17 & 18 & 19 & 20 & 21 \\
\hline
\end{tabular}

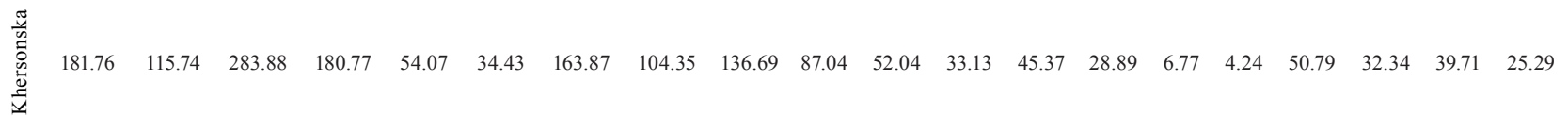

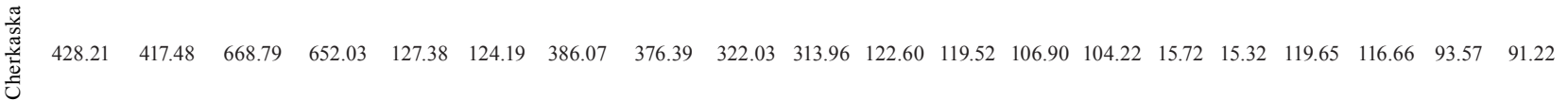

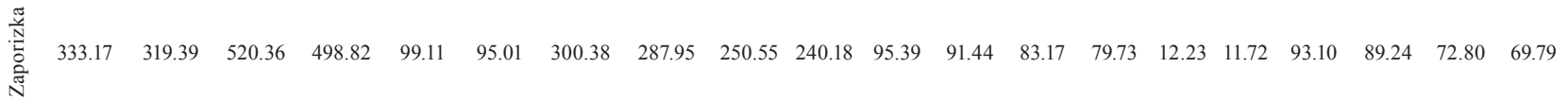

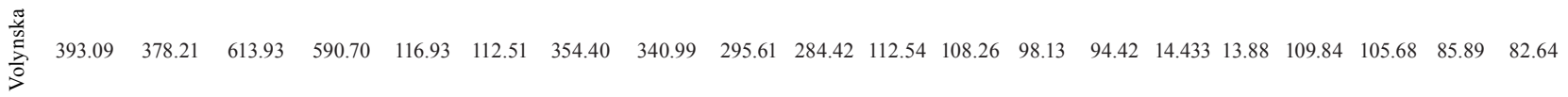

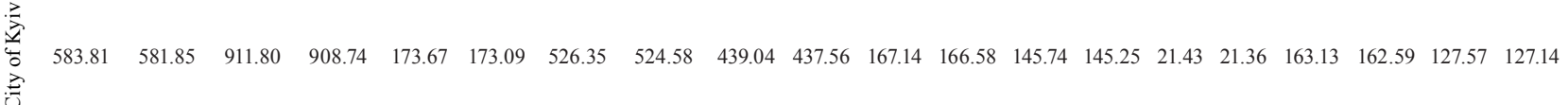

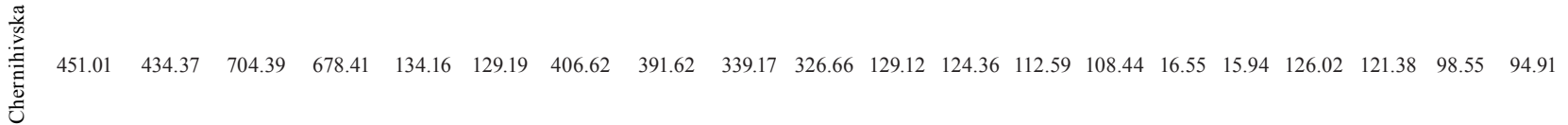

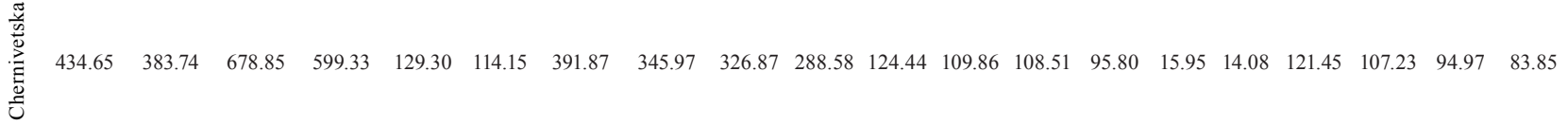

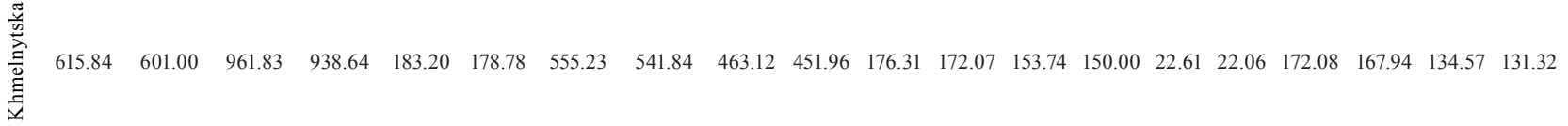

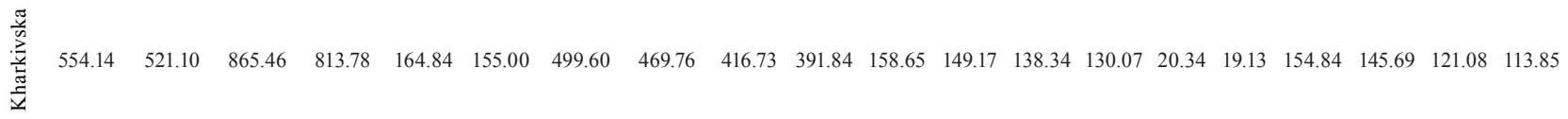

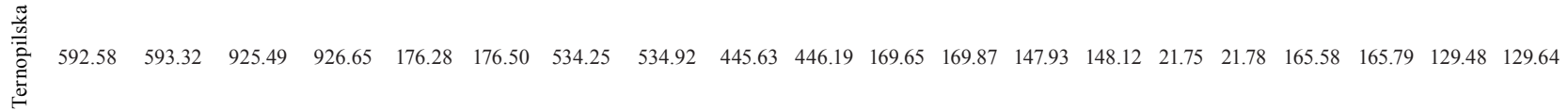

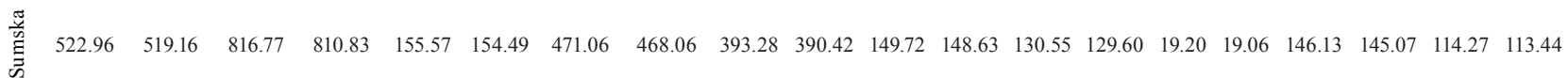

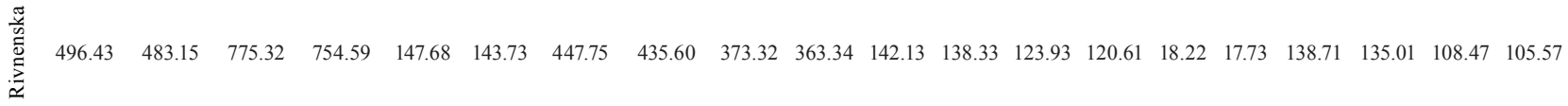




\section{Continuation of Table 3}

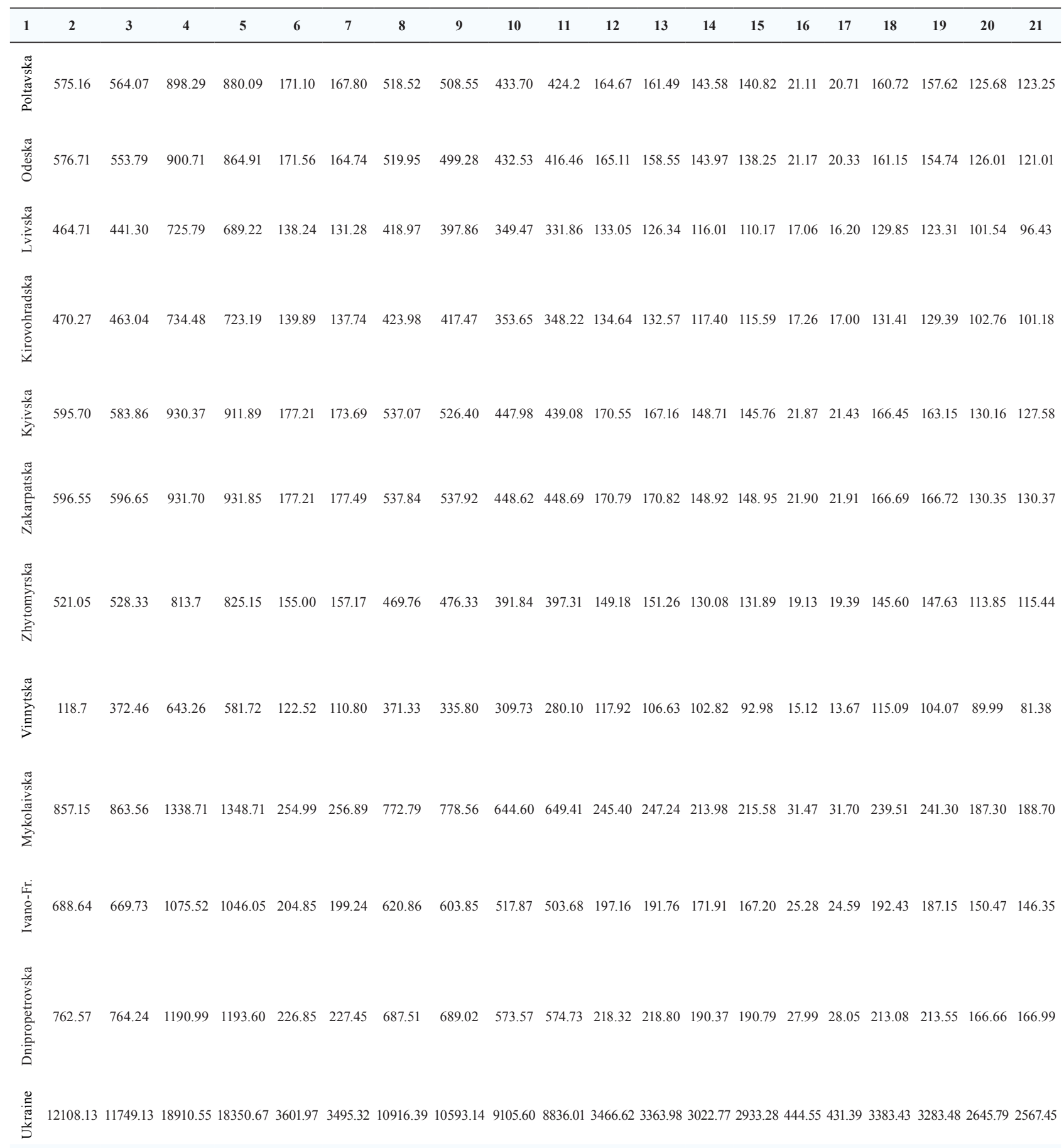

The second group contained such medicines as Amlodipine, Clopidogrel, Enalapril in all regions except those referred to the first group and Magnicor by the indicator in the Vinnytska region. Thus, Magnicor was in the third group as in 2019. Therefore, in 2019 and 2020 Acetylsalicylic acid, in case of its inclusion in the program, has the lowest forecasting overall average indicator of drug reimbursement in the Khersonska region -1.89 and 1.36 USD per one patient. In case of inclusion of the drug in the program In case of its inclusion in the program Magnicor has also the highest indicator - 225.36 USD per one patient in 2019 and 210.99 USD in 2020. 
Table 4

The overall average indicators of forecasting drug reimbursement in the regions of Ukraine per one patient in 2019 (USD)

\begin{tabular}{|c|c|c|c|c|c|c|c|c|c|c|}
\hline Regions & 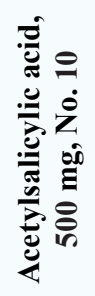 & 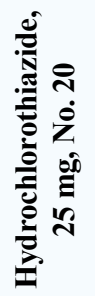 & 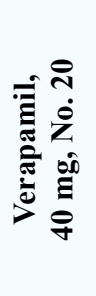 & 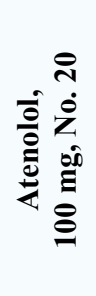 & 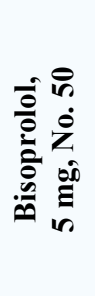 & 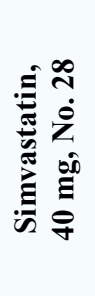 & 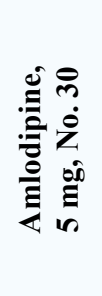 & 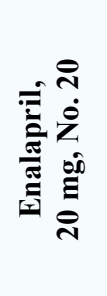 & 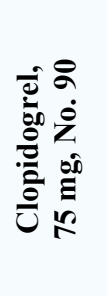 & 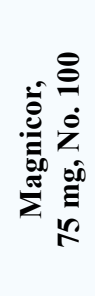 \\
\hline City of Kyiv & $4.44^{*}$ & 26.42 & 30.18 & 33.78 & 34.61 & 35.96 & 90.92 & 109.00 & 120.90 & 188.82 \\
\hline Chernihivska & 4.09 & 24.37 & 27.84 & 31.16 & 31.93 & 33.17 & 83.86 & 100.53 & 111.51 & 174.15 \\
\hline Chernivetska & 3.86 & 22.98 & 26.25 & 29.38 & 30.10 & 31.28 & 79.07 & 94.80 & 105.15 & 164.22 \\
\hline Cherkaska & 3.85 & 22.91 & 26.18 & 29.30 & 30.02 & 31.19 & 78.85 & 94.53 & 104.85 & 163.76 \\
\hline Khmelnytska & 4.24 & 25.23 & 28.83 & 32.27 & 33.06 & 34.35 & 86.84 & 104.10 & 115.47 & 180.34 \\
\hline Khersonska & 1.89 & 11.24 & 12.84 & 14.37 & 14.72 & 15.30 & 38.67 & 46.36 & 51.42 & 80.31 \\
\hline Kharkivska & 3.73 & 22.19 & 25.35 & 28.37 & 29.07 & 30.21 & 76.36 & 91.55 & 101.54 & 158.59 \\
\hline Ternopilska & 4.63 & 27.54 & 31.47 & 35.22 & 36.09 & 37.49 & 94.79 & 113.63 & 126.04 & 196.85 \\
\hline Sumska & 4.40 & 26.18 & 29.91 & 33.47 & 34.30 & 35.64 & 90.09 & 108.00 & 119.80 & 187.10 \\
\hline Rivnenska & 4.06 & 24.16 & 27.60 & 30.89 & 31.65 & 32.89 & 83.14 & 99.68 & 110.56 & 172.67 \\
\hline Mykolaivska & 5.30 & 31.53 & 36.02 & 40.32 & 41.31 & 42.92 & 108.51 & 130.09 & 144.29 & 225.36 \\
\hline Odeska & 4.00 & 23.80 & 27.19 & 30.43 & 31.18 & 32.40 & 81.90 & 98.19 & 108.91 & 170.09 \\
\hline Poltavska & 4.55 & 27.09 & 30.95 & 34.64 & 35.49 & 36.88 & 93.22 & 111.76 & 123.96 & 193.61 \\
\hline Lvivska & 3.93 & 23.37 & 26.70 & 29.88 & 30.62 & 31.81 & 80.42 & 96.42 & 106.94 & 167.02 \\
\hline Kirovohradska & 4.22 & 25.11 & 28.69 & 32.11 & 32.90 & 34.19 & 86.43 & 103.61 & 114.92 & 179.49 \\
\hline Kyivska & 5.10 & 30.38 & 34.70 & 38.84 & 39.80 & 41.35 & 104.54 & 125.33 & 139.01 & 217.10 \\
\hline $\begin{array}{c}\text { Ivano- } \\
\text { Frankivska }\end{array}$ & 4.01 & 23.89 & 27.30 & 30.56 & 31.31 & 32.53 & 82.23 & 98.59 & 109.35 & 170.78 \\
\hline Zaporizka & 3.97 & 23.64 & 27.01 & 30.23 & 30.98 & 32.19 & 81.36 & 97.55 & 108.19 & 168.98 \\
\hline Zakarpatska & 4.64 & 27.59 & 31.52 & 35.29 & 36.15 & 37.56 & 94.96 & 113.85 & 126.27 & 197.22 \\
\hline Zhytomyrska & 4.58 & 27.23 & 31.11 & 34.82 & 35.68 & 37.07 & 93.72 & 112.36 & 124.63 & 194.64 \\
\hline $\begin{array}{c}\text { Dnipro- } \\
\text { petrovska }\end{array}$ & 4.61 & 27.46 & 31.37 & 35.11 & 35.97 & 37.38 & 94.49 & 113.28 & 125.65 & 196.23 \\
\hline Volynska & 3.98 & 23.70 & 27.08 & 30.31 & 31.05 & 32.27 & 81.56 & 97.79 & 108.46 & 169.39 \\
\hline Vinnytska & 3.31 & 19.73 & 22.54 & 25.22 & 25.84 & 26.85 & 67.88 & 81.38 & 90.27 & 140.98 \\
\hline
\end{tabular}

Note: $\square$ - Group I 1.89-76.38 USD;

- Group II 76.39-150.87 USD;

- Group III 150.88-225.36 USD

Among the medicines included in the program "Available medicines" the lowest indicator is for Hydrochlorothiazide, $25 \mathrm{mg}$, No.20, in the Khersonska region both in 2019 and in $2020-11.24$ and 8.08 USD, respectively. The highest indicator is for Clopidogrel, $75 \mathrm{mg}$, No. $90-144.29$ and 135.09 USD in the Mykolaivska region.

In particular, both in 2019 and in 2020 the lowest indicator of consumption of all drugs studied is in the Khersonska region, and the highest indicator is in the Mykolaivska region. There is also an uneven consumption of medicines involved in the program among the regions of Ukraine. This is due to the fact that the uneven number of pharmacies participating in the program by regions of the country is involved.

Taking into account the further prospect of expanding the government program it should be noted that Acetylsalicylic acid is an affordable, effective and safe antiplatelet agent in the treatment of CVD and is included in the list of essential drugs recommended by the WHO in the doses of 
500 and $100 \mathrm{mg}$. Therefore, its inclusion in the list of the drugs reimbursed is an effective step towards improving pharmaceutical care for patients with CVD.

Table 5

The overall average indicators of forecasting drug reimbursement cost in the regions of Ukraine per one patient in 2020 (USD)

\begin{tabular}{|c|c|c|c|c|c|c|c|c|c|c|}
\hline Regions & 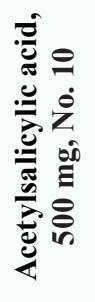 & 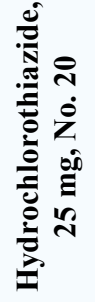 & 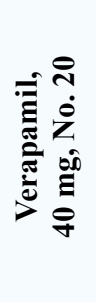 & 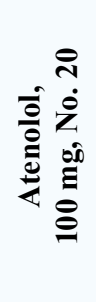 & 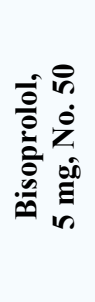 & 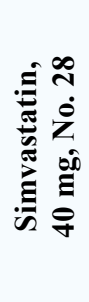 & 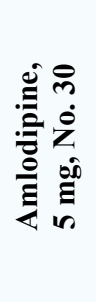 & 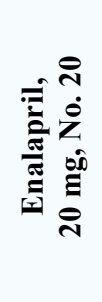 & 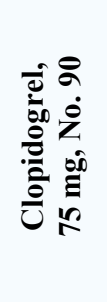 & 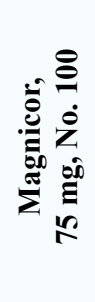 \\
\hline Khersonska & 1.36 & 8.08 & 9.24 & 10.34 & 10.59 & 11.01 & 27.82 & 33.36 & 37.00 & 57.78 \\
\hline Vinnytska & 3.15 & 18.77 & 21.45 & 24.00 & 24.59 & 25.55 & 64.60 & 77.45 & 85.90 & 134.16 \\
\hline Cherkaska & 3.50 & 20.85 & 23.82 & 26.66 & 27.31 & 28.38 & 71.74 & 86.01 & 95.40 & 148.99 \\
\hline Kharkivska & 3.62 & 21.54 & 24.61 & 27.54 & 28.22 & 29.32 & 74.13 & 88.87 & 98.57 & 153.95 \\
\hline Lvivska & 3.69 & 21.98 & 25.11 & 28.11 & 28.80 & 29.92 & 75.65 & 90.69 & 100.59 & 157.10 \\
\hline Odeska & 3.84 & 22.86 & 26.12 & 29.23 & 29.95 & 31.12 & 78.67 & 94.32 & 104.61 & 163.38 \\
\hline Zaporizka & 3.89 & 23.16 & 26.46 & 29.62 & 30.35 & 31.53 & 79.71 & 95.56 & 106.00 & 165.55 \\
\hline Chernivetska & 3.91 & 23.27 & 26.59 & 29.76 & 30.49 & 31.68 & 80.09 & 96.02 & 106.50 & 166.34 \\
\hline Volynska & 3.92 & 23.32 & 26.64 & 29.82 & 30.55 & 31.74 & 80.24 & 96.20 & 106.70 & 166.65 \\
\hline Chernihivska & 3.94 & 23.43 & 26.76 & 29.96 & 30.69 & 31.89 & 80.62 & 96.65 & 107.20 & 167.43 \\
\hline $\begin{array}{c}\text { Ivano- } \\
\text { Frankivska }\end{array}$ & 3.99 & 23.75 & 27.14 & 30.38 & 31.12 & 32.34 & 81.75 & 98.01 & 108.71 & 169.78 \\
\hline Rivnenska & 4.00 & 23.81 & 27.20 & 30.45 & 31.19 & 32.41 & 81.94 & 98.23 & 108.95 & 170.16 \\
\hline Kirovohradska & 4.09 & 24.36 & 27.83 & 31.15 & 31.92 & 33.16 & 83.84 & 100.51 & 111.48 & 174.12 \\
\hline Khmelnytska & 4.18 & 24.86 & 28.40 & 31.79 & 32.57 & 33.84 & 85.55 & 102.56 & 113.76 & 177.66 \\
\hline Sumska & 4.37 & 26.03 & 29.74 & 33.29 & 34.10 & 35.44 & 89.58 & 107.40 & 119.12 & 186.04 \\
\hline Zakarpatska & 4.53 & 26.94 & 30.78 & 34.45 & 35.29 & 36.67 & 92.70 & 111.14 & 123.27 & 192.53 \\
\hline City of Kyiv & 4.56 & 27.14 & 31.01 & 34.71 & 35.56 & 36.95 & 93.41 & 111.98 & 124.21 & 193.99 \\
\hline Poltavska & 4.59 & 27.33 & 31.22 & 34.95 & 35.81 & 37.21 & 94.06 & 112.76 & 125.07 & 195.34 \\
\hline $\begin{array}{c}\text { Dnipro- } \\
\text { petrovska }\end{array}$ & 4.64 & 27.64 & 31.58 & 35.35 & 36.22 & 37.63 & 95.13 & 114.05 & 126.50 & 197.57 \\
\hline Ternopilska & 4.70 & 27.96 & 31.94 & 35.75 & 36.63 & 38.06 & 96.21 & 115.34 & 127.94 & 199.81 \\
\hline Zhytomyrska & 4.71 & 28.02 & 32.01 & 35.83 & 36.71 & 38.14 & 96.42 & 115.59 & 128.21 & 200.24 \\
\hline Kyivska & 4.79 & 28.50 & 32.56 & 36.44 & 37.34 & 38.80 & 98.08 & 117.58 & 130.41 & 203.68 \\
\hline Mykolaivska & 4.96 & 29.52 & 33.73 & 37.75 & 38.68 & 40.19 & 101.59 & 121.80 & 135.09 & 210.99 \\
\hline
\end{tabular}

Note: $\square$ - Group I 1.36-71.23 USD;

- Group II 71.24-141.11USD; $\square$ - Group III 141.12-210.99 USD

For 2019 the forecasting amount of drug reimbursement for Clopidogrel is 12108.13 USD thousand, and for Acetylsalicylic acid (in case of its inclusion in the program) it is 444.55 USD thousand, therefore, it is 11663,57 USD thousand (by $27.24 \%$ ) less. For example, if a physician prescribes medicines containing acetylsalicylic acid to patients (if the medicine is well tolerated), instead of Clopidogrel, the state will be able to distribute and save budget funds more rationally [11, 12]. 


\section{Discussion}

Improvement and provision of high-quality and affordable care to patients with socially important pathologies is a priority in development and formation of an effective healthcare system [13]. The study of decision-making in drug reimbursement author of the inventory increase spending on health in the world and part reimbursement mechanisms in public policy [14]. Author Johnson P.E. in his work «Pharmaceutical reimbursement: an overview» describes the benefits of electronic information programs for the health system and their participation in the process of reimbursement of the cost of medicines [15]. In their work «Pharmaceutical pricing and reimbursement in China» scientists emphasize that regulation of the healthcare system is necessary to ensure transparency at all stages of decision making and, as a consequence, rationalization of all processes to improve the quality standards of treatment [16].

For example, in the study «Health Care Economics: The Real Source of Reimbursement Problems» the author describes the problems faced by the healthcare system in the UK when reimbursing the cost of services to patients [17]. As a variant to solve the problem the author offers new models for reimbursement of services used by the patient in the process of treatment.

In another study «Evolution of drug reimbursement in Canada: The Pan-Canadian pharmaceutical alliance for new drugs», the authors noted that public authorities, medical and pharmaceutical workers, patients and other participants involved in the process of providing care to patients need to improve mechanisms for reimbursement of drugs and services through negotiations, as well as a clear definition of duties and obligations for all participants [18]. The authors of the article «The future of cardiovascular care: From affordable care to the academic medical center» identified problems in the healthcare system of America associated with budgetary costs for patients. Spending on programs to provide CVD patients with medical and pharmaceutical care is increasing, and therefore, it is necessary to redistribute risks and pay more attention to optimizing the cost of services $[19,20]$.

In Ukraine, forecasting the indicators for drug reimbursement is performed for the first time for patients with CVD within the framework of the government program and is of significant importance in the further process of reforming and developing the healthcare system. Thanks to the prognosis and possible further expansion of the program "Available medicines" for drug reimbursement patients with CVD will be able to get help.

\section{Conclusion}

1. CVD is the leading cause of premature mortality among the world's working-age population. The high prevalence and subsequent mortality from CVD are due to a number of factors, including heredity, concomitant diseases, ecology, inadequate therapy and low solvency of the population.

2. According to the results for forecasting the volume of drug reimbursement to patients with CVD under the government program it has been found that Clopidogrelhas the 12108.13 USD thousand and 11908.24 USD Thousand, Enalaprilthe takes second position - 1 highest indicator 10916.4 USD thousand in 2019 and 10736.18 USD thousand in 2020, while Amlodipine occupies the third position - 9105.60 USD Thousand and 8955.28 USD thousand.

3. Among the medicines not included in the government program the largest forecasting amount required for reimbursement (in case of inclusion in the program) is 18910.55 USD Thousand in 2019 and 18598.36 USD Thousand in 2020 for Magnicor, and the least amount is 444.55 USD Thousand and 437.22 USD Thousand for Acetylsalicylic acid, respectively.

4. Despite the fact that the treatment with Acetylsalicylic acid should be carried out on a regular basis in patients with hypertension and coronary artery disease, it is necessary to include this medicine or its analogs in accordance with clinical protocols and international standards of treatment to the program "Available medicines". The inclusion of medicines of Acetylsalicylic acid in the reimbursement program will make it possible to reduce morbidity and mortality from CVD, as well as guarantee access to high-quality and effective pharmacotherapy for all segments of the population. 


\section{References}

[1] WHO official website. Available at: http://who.int/ru/

[2] World Heart Federation. Available at: http://www.worldheart.org/

[3] About the approval of the Healthcare Financing Reform Concept (2016). Kabinet Ministriv Ukrainy No. 1013-p. 30.11.2016. Available at: http://zakon.rada.gov.ua/laws/show/1013-2016- \%D1 \%80

[4] Government program "Available medicines". Available at: http://iky.gov.ua/

[5] USAID "Safe and affordable drugs" project. Apteka, 16 (1137). Available at: https://www.apteka.ua/article/454406

[6] US Centers for Disease Control and Prevention. Available at: https://www.cdc.gov/

[7] Cochrane Collaboration. Available at: https://www.cochrane.org/

[8] State Statistics Service of Ukraine. Available at: http://www.ukrstat.gov.ua/

[9] Official website of the Ministry of Health of Ukraine. Available at: http://moz.gov.ua/

[10] Medical home model reimbursement rates for ihs\& tribal health facilities in Arizona (2011). Available at: https://www. azahcccs.gov/AmericanIndians/Downloads/Consultations/Meetings/2011/Aug2/AHCCCSSupportingDocumentation AIHMPFinalReport.pdf

[11] Medicaid Drug Rebate Program. Available at: https://www.medicaid.gov/medicaid/prescription-drugs/medicaid-drug-rebate-program/index.html

[12] Yakovenko, E. P., Krasnolobova, L. P., Yakovenko, A. V., Agafonova, N. A., Ivanov, A. N., Bogomolova E. A. et. al. (2013). Effect of acetylsalicylic acid formulations on morpho-functional status of gastric mucosa in elderly cardiac patients. Heart: a journal for practicing physicians, 3, 145-150.

[13] The National Center for Biotechnology Information. Available at: https://www.ncbi.nlm.nih.gov/

[14] Franken, M. G. (2014). Decision making in drug reimbursement. Erasmus University Rotterdam. Available at: http://hdl.handle.net/1765/77229

[15] Johnson, P. E. (2008). Pharmaceutical reimbursement: An overview. American Journal of Health-System Pharmacy, 65 (2), 4-10. doi: http://doi.org/10.1093/ajhp/65.004

[16] Hu, J., Mossialos, E. (2016). Pharmaceutical pricing and reimbursement in China: When the whole is less than the sum of its parts. Health Policy, 120 (5), 519-534. doi: http://doi.org/10.1016/j.healthpol.2016.03.014

[17] Fifer, R. (2016). Health Care Economics: The Real Source of Reimbursement Problems. CCC-A American Speech-Language-Hearing Association (ASHA).

[18] Husereau, D., Dempster, W., Blanchard, A., Chambers, J. (2014). Evolution of Drug Reimbursement in Canada: The Pan-Canadian Pharmaceutical Alliance for New Drugs. Value in Health, 17 (8), 888-894. doi: http://doi.org/10.1016/j.jval.2014.08.2673

[19] Konstam, M. A. (2018). The future of cardiovascular care: from affordable care to the academic medical center. Transactions of the American Clinical and Climatological Association, 129, 301-311.

[20] Konstam, M. A., Hill, J. A., Kovacs, R. J., Harrington, R. A., Arrighi, J. A., Khera, A. (2017). The Academic Medical System. Journal of the American College of Cardiology, 69 (10), 1305-1312. doi: http://doi.org/10.1016/j.jacc.2016.12.024

Received date 07.05.2019

Accepted date 19.06.2019

Published date 31.07.2019
(C) The Author(s) 2019

This is an open access article under the CC BY license (http://creativecommons.org/licenses/by/4.0). 